\title{
Independently derived Murine Glomerular Immune Deposit-forming Anti-DNA Antibodies Are Encoded by Near-identical $V_{H}$ Gene Sequences
}

Michael S. Katz, Mary H. Foster, and Michael P. Madaio

Penn Center for Molecular Studies of Kidney Disease and Renal and Electrolyte Division,

The University of Pennsylvania School of Medicine, Philadelphia, Pennsylvania 19104

\begin{abstract}
To examine the influence of variable region sequences on the capacity of individual lupus autoantibodies (autoAb) to form glomerular immune deposits, the complete $V_{H}$ and $V_{L}$ region sequences of three anti-DNA mAb that produced morphologically similar immune deposits after administration to normal mice were determined. The Ig were independently derived from 1-mo-old (H238, IgM), 3-mo-old (H8, IgG2a), and 6-mo-old (H161, IgG3) MRL-lpr / Ipr mice, and they all produced subendothelial and mesangial immune deposits after passive transfer to normal mice. In addition, $\mathrm{H} 238$ and $\mathrm{H161}$ produced granular deposits in small extraglomerular vessels. The mAb had nearly identical $V_{H}$ gene sequences; $\mathrm{H8}$ differed from $\mathrm{H} 238$ and $\mathrm{H161}$ by a single nucleotide in FR1 that resulted in a histidine for glutamine substitution. This $V_{H}$ gene sequence was also $>99 \%$ homologous to another anti-DNA Ab (termed H241), that we previously reported to produce glomerular immune deposits in a similar morphologic pattern. $\mathrm{H161}$ and $\mathrm{H} 238$ were encoded by DFL16 and $J_{H} 2$ genes, whereas $H 8$ was encoded by a $J_{H} 4$ gene. Different $V_{k}$ family genes were used to encode the three mAb, however H161 and $\mathrm{H} 238$ both used a $J_{k} 5$ gene. The results indicate that an identical or highly related $V_{H}$ gene is used to encode a subgroup of murine lupus autoAb that share immune deposit forming properties. Furthermore, they raise the possibility that amino acid residues independent from those encoded by $V_{H}$ genes may be influential in immune deposit formation at extraglomerular sites. (J. Clin. Invest. 1993. 91:402-408.) Key words: anti-DNA antibody • systemic lupus erythematosus $\bullet V_{H}$ gene $\bullet$ autoimmunity $\bullet$ glomerulonephritis
\end{abstract}

\section{Introduction}

The influence of specific $\mathrm{V}$ gene sequences on the production of nephritogenic lupus autoantibodies (autoAb) ${ }^{1}$ has been the focus of our research. Selective $V$ gene use among pathogenic Ig is suggested by the observation that properties associated with the antigen $(\mathrm{Ag})$ binding region distinguish nephritogenic Ig from their serum counterparts. In this regard, we and others have demonstrated that Ig eluted from glomeruli of individuals

Address correspondence to Michael P. Madaio, M.D., 700 Clinical Research Building, University of Pennsylvania, 422 Curie Boulevard, Philadelphia, PA 19104-6144.

Received for publication 30 March 1992 and in revised form 26 August 1992.

1. Abbreviations used in this paper: $\mathrm{Ab}$, antibodies; $\mathrm{Ag}$, antigens.

J. Clin. Invest.

(C) The American Society for Clinical Investigation, Inc. $0021-9738 / 93 / 02 / 0402 / 07 \$ 2.00$

Volume 91, February 1993, 402-408 with active nephritis are enriched for anti-DNA and other autoantigen (autoAg) binding properties (1-7). In comparison to serum Ig, nephritogenic Ig are highly cross-reactive; individual Ig eluted from individuals with lupus nephritis bind to multiple autoAg, including cell surface and basement membrane antigens normally present within the glomerulus $(3,4,8)$. The presence and relative concentration of Ig with shared idiotypes among nephritogenic Ig provides further support for an influential role of the Ag binding region in the formation of glomerular immune deposits $(3-5,9,10)$.

To address this issue directly, we reasoned that it would be useful to determine the $\mathrm{V}$ gene sequences of auto $\mathrm{Ab}$ with nephritogenic properties. For purposes of identifying nephritogenic autoAb, the capacity of individual MRL-lpr/lpr-derived monoclonal anti-DNA Ab to produce glomerular immune deposits in normal mice was determined (11). In these initial studies, the monoclonal autoAb were selected on the basis of $\mathrm{Ag}$ binding properties shared with Ig eluted from the kidneys of mice with active nephritis; the selected $\mathrm{mAb}$ were subsequently administered to normal mice. Consequently a subset of monoclonal anti-DNA Ab were identified that reproducibly formed glomerular immune deposits. Particularly noteworthy, the location of immune deposits within glomeruli varied and was dependent on the administered monoclonal anti-DNA Ab, and this was associated with different disease patterns. Furthermore many Ig did not produce immune deposits. These observations indicate that not all anti-DNA $\mathrm{Ab}$ are pathogenic, and they raise the possibility that the $A b \mathrm{~V}$ region influences both the capacity of individual autoAb to form immune deposits and the site of immune deposit formation within the glomerulus.

A relevant question that evolved from these studies is: Are autoAb that produce similar patterns of glomerular immune deposits encoded by related $\mathrm{V}$ genes? To address this question, in the present studies, the heavy and light chain $\mathrm{V}$ gene sequences of three monoclonal anti-DNA Ab that produced mesangial and subendothelial immune deposits after transfer to normal mice were determined. These particular monoclonal anti-DNA Ab were selected, because they produced morphologically similar patterns of immune deposits. Furthermore, to exclude the potential bias of examining clonally related $\mathrm{Ig}$ from an individual mouse, the $\mathrm{Ig}$ were intentionally selected from three MRL-lpr/lpr mice of different ages (12).

\section{Methods}

Selection of $m A b$. As indicated above, our aim was to determine the $\mathrm{V}$ region sequences of $\mathrm{mAb}$ that reproducibly produced glomerular immune deposits after passive transfer to normal mice. For this purpose, monoclonal anti-DNA Ab were selected from a large panel of hybridomas derived from MRL-lpr/lpr mice of varying ages (12), on the basis of shared cross-reactive $\mathrm{Ag}$ binding properties with Ig eluted from the kidneys of 3-4-mo-old MRL-lpr/lpr mice with active nephritis (3). After passive transfer, a subset of monoclonal anti-DNA Ab reproducibly produced persistent glomerular immune deposits when adminis- 
tered as hybridomas and as purified Ig to normal ( $A K R \times D B A) 2$ mice (11). This recipient strain was selected because of histocompatibility with both the MRL-lpr-derived B cells and the NS-1 fusion partner used to produce the hybridomas. Noteworthy: $(a)$ the administered anti-DNA Ab was the only detectable Ig within the lesions; $(b)$ the location of the glomerular immune deposits varied with the administered antibody; and $(c)$ the different sites of immune deposit formation were associated with distinct histologic and clinical profiles. Furthermore, there were monoclonal anti-DNA Ab that either did not produce immune deposits or produced only minimal mesangial deposits (direct immunofluorescence), unassociated with light or electron microscopic abnormalities. From the group of immune deposit-forming $\mathrm{Ab}$, three (termed H8, H161, and $\mathrm{H} 238$ ) were selected for further analysis because they produced an indistinguishable histological pattern characterized by persistent mesangial and subendothelial immune deposits (as determined by immunofluorescence and electron microscopy).
Two of the mAb ( $\mathrm{H} 161$ and $\mathrm{H} 238)$ also produced vascular immune deposits, whereas the other ( $\mathrm{H8}$ ) did not. The mice that received the H238 (IgM) hybridomas developed proliferative glomerulonephritis and proteinuria, and the $\mathrm{H} 8$ animals developed proteinuria. A typical example of the immune deposits produced by these $\mathrm{mAb}$ is illustrated in Fig. 1. The in vivo and in vitro characteristics of these three $\mathrm{mAb}$ are summarized in Table I.

$V$ gene sequence determination and analysis. Total RNA was isolated from each $\mathrm{B}$ cell hybridoma by the guanidium/ $\mathrm{CsCl}$ method as previously described (13). Full-length cDNA was synthesized from 80 $\mu \mathrm{g}$ of total RNA by primer extension using avian myeloblastosis virus reverse transcriptase (Boehringer-Mannheim, Corp., Indianapolis, IN), RNase H (Bethesda Research Laboratories, Gaithersburg, MD), DNA polymerase 1 (NEN) and either $\mathrm{C} \gamma, \mathrm{C} u$, or $\mathrm{C} k$ primers including 5'(GGCCAGTGGATAGAC) 3', (IgG2a); 5'(GACCAAGGGATAGAC)3', (IgG3); 5'(CAGGAGACGATGGGGGA)3, IgM; and
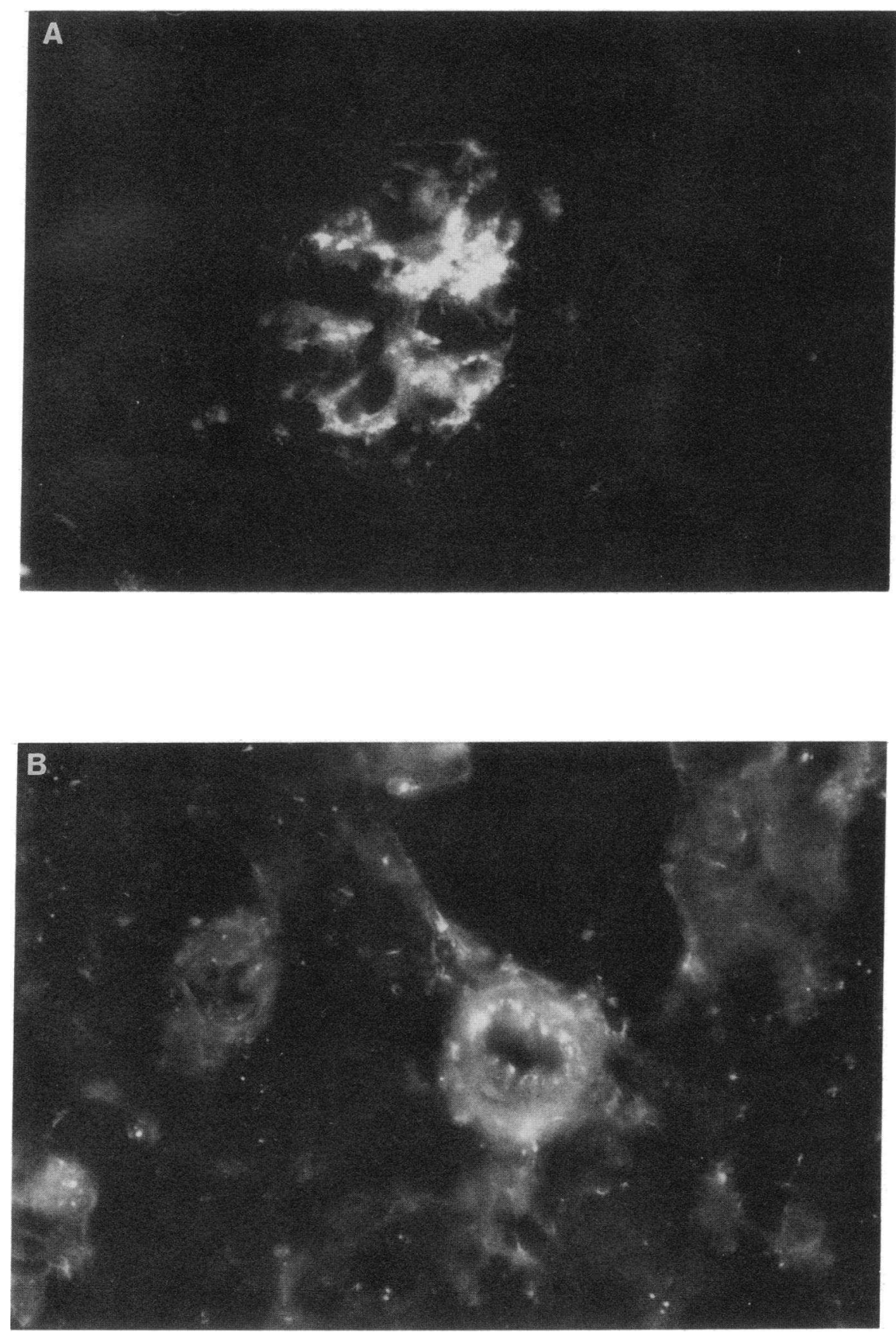

Figure 1. $(A)$ Glomerular immune deposits after administration of $\mathrm{H} 8$ hybridomas to normal mice; direct immunofluorescence $(\times 400)$. Immune deposits were visualized in a capillary wall and mesangial distribution as previously reported for $\mathrm{H} 161$ and $\mathrm{H} 238$. (B) Immune deposits within small vessels after the administration of $\mathrm{H} 161$ to normal mice. Direct immunofluorescence $(\times 400)$. H238 also produced vascular immune deposits, whereas $\mathrm{H} 8$ did not. 
Table I. Characteristics of MRL 1pr/1pr Immune Deposit-forming mAb

\begin{tabular}{|c|c|c|c|c|c|c|c|c|c|c|}
\hline \multirow[b]{2}{*}{$\mathrm{mAb}$} & \multirow[b]{2}{*}{ Age } & \multirow[b]{2}{*}{ Isotype } & \multicolumn{3}{|c|}{ Antigen binding properties* } & \multirow[b]{2}{*}{ SmRNP } & \multirow[b]{2}{*}{ Laminin } & \multirow{2}{*}{$\underset{\mathrm{mg} / \text { day }}{\mathrm{U}_{\mathrm{p}}}$} & \multicolumn{2}{|c|}{ Immune deposits } \\
\hline & & & $\mathbf{V}_{\mathbf{H}}$ & ssDNA & dsDNA & & & & Glo & Vas \\
\hline 8 & $3 \mathrm{mo}$ & IgG2a & J558 & ++ & ++ & ++ & - & $1.5 \pm 0.4$ & mes/subend & - \\
\hline 161 & $6 \mathrm{mo}$ & IgG3 & J558 & + & - & +++ & - & $1.0 \pm 0.2$ & mes/subend & + \\
\hline 238 & $1 \mathrm{mo}$ & IgM & J558 & + & - & - & + & $1.9 \pm 0.6$ & mes/subend & + \\
\hline
\end{tabular}

* As determined by ELISA: scale = minimum concentration of $\mathrm{mAb}$ that produced OD405 $>0.500$, when positive control mAb reading was between 1.0 and 1.2 and negative control $\mathrm{mAb}<0.05 ;+++=<0.1 \mu \mathrm{g} / \mathrm{ml} ;++=0.1-1.0 \mu \mathrm{g} / \mathrm{ml} ;+=1-10 \mu \mathrm{g} / \mathrm{ml} ;-=>10 \mu \mathrm{g} / \mathrm{ml}$. Age indicates age of mouse from which hybridoma was derived. Immune deposits refers to the pattern of immune deposit formation after administration to normal mice. Glo, glomerular; Mes, mesangial; subend, subendothelial; and Vas, vascular. $V_{H}$ refers to $V_{H}$ gene family use by the $\mathrm{mAb}$. $U_{\mathrm{P}}$, quantitation of proteinuria/24 $\mathrm{h}$; the level (mean \pm S.D.) for the normal 4-6 wk female (AKRxDBA2)F1 mice was <1.0 mg/d.

5'(CTGCTCACTGGATGGTGGGA) 3', $\mathrm{V}_{\mathrm{k}}(13)$. The cDNA was blunt ended with T4 DNA polymerase and ligated into the Smal-digested M13mp18 RF (NEBL) as described (13). The M13 RF was transformed into DH5-aF TQ (Bethesda Research Laboratories). Colonies were screened with chain specific ${ }^{32} \mathrm{P}$-labeled oligoprobes, including 5'(TGGGGCTGTTGTTTT), IgG2a; 5'(TGGGGCTGTTGTTGT), IgG3; 5'(ATTTGGGAAGGACTGAC) 3', IgM; and 5'(AGATGGATACAGTTGGT), $\mathrm{V}_{\mathbf{k}}$. Positive plaques were subcloned, purified and sequenced by incorporation of dideoxynucleotides using the Sequenase Version 2.0 Kit (United States Biochemical Corp., Cleveland,
$\mathrm{OH})$. The sequences of at least two distinct cDNA clones containing complete $\mathrm{V}$ region sequence were determined for each Ig chain. Sequences were analyzed using the MacVector program and GenBank.

\section{Results}

The nucleotide and deduced amino acid sequences of the heavy chain variable region genes of $\mathrm{H} 8, \mathrm{H} 161$, and $\mathrm{H} 238$ are illustrated in Fig. 2. There is identity in the $V_{H}$ gene for $\mathrm{H} 161$

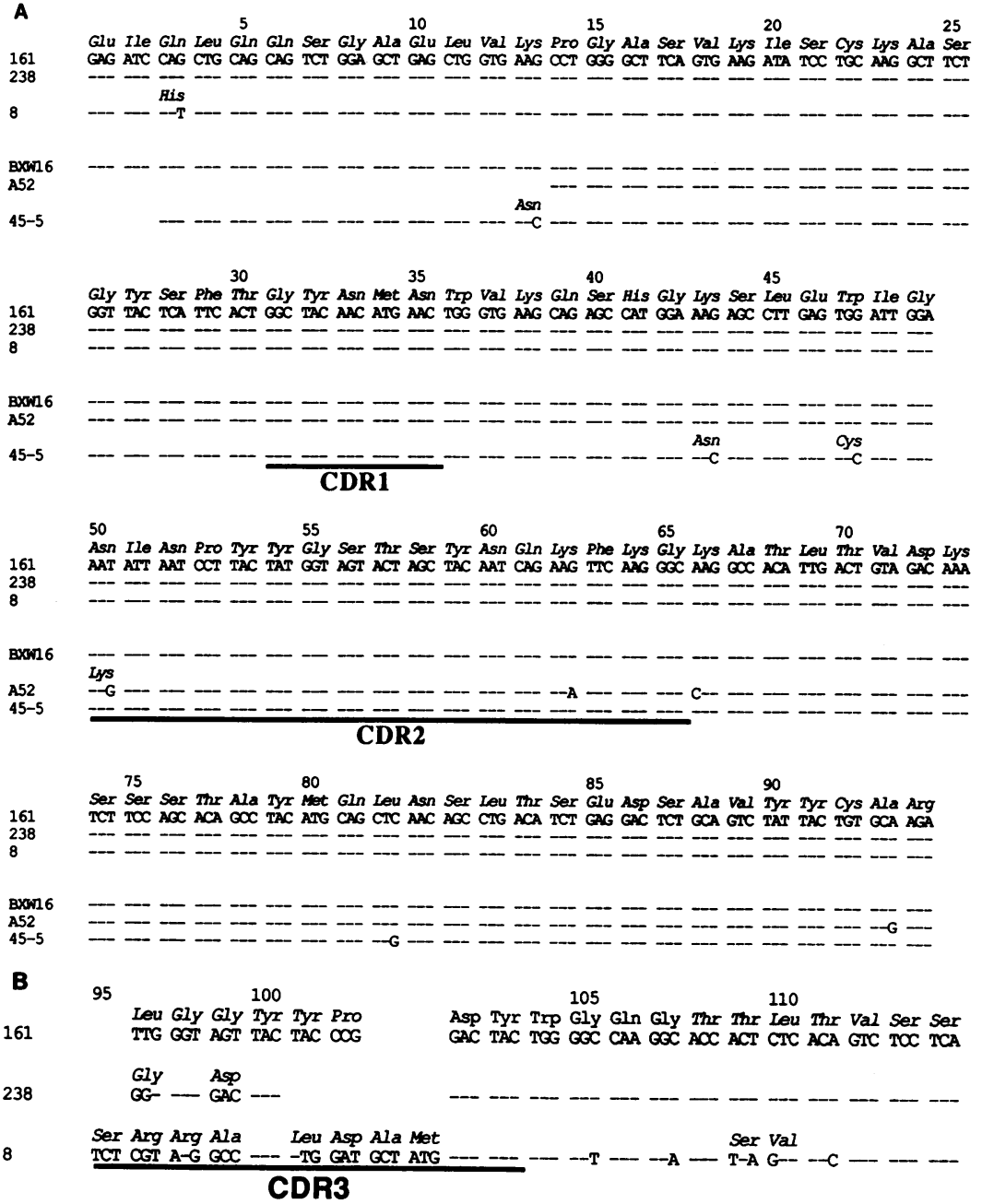

Figure 2. Nucleotide and deduced a.a. sequences of the heavy chain variable region genes of $\mathrm{H} 161, \mathrm{H} 238$, and $\mathrm{H8}$. In this and subsequent figures, the dashes indicate identity with the residue given in the top line. Codon numbering is according to Kabat et al. (14); $\mathrm{CDR}$ are underlined. $(A) \mathrm{V}_{\mathrm{H}}$ gene sequences. In addition, the $\mathrm{V}_{\mathrm{H}}$ gene sequences of three anti-DNA $\mathrm{Ab}$, BXW16 (15), A52 (16), and 45-5 (17) identified by GenBank search that showed $\geq 99 \%$ homology with $\mathrm{V}_{\mathrm{H}} \mathrm{H} 161, \mathrm{H} 238$, and $\mathrm{H} 8$ are illustrated. BXW16 is a $(\mathrm{NZB} \times \mathrm{W}) \mathrm{F} 1$ IgM mAB, A52 a $(\mathrm{NZB} \times \mathrm{W}) \mathrm{F} 1$ IgG2b mAb and 45-5, an MRL $1 \mathrm{pr}$ IgG2a mAb. $(B)$ $D_{H}$ and $J_{H}$ gene sequences. 
and $\mathrm{H} 238$, and $\mathrm{H} 8$ differs only by a histidine for glutamine substitution in FR1. $\mathrm{H} 161$ and $\mathrm{H} 238$ were encoded by a DFL16 gene, whereas H8 used a DSp2 gene. $\mathrm{H} 161$ and $\mathrm{H} 238$ were encoded by the $\mathrm{J}_{\mathrm{H}} 2$ gene, whereas $\mathrm{H} 8$ was encoded by the $\mathrm{J}_{\mathrm{H}} 4$ gene.

The nucleotide and deduced amino acid sequences of the light chain variable region genes of $\mathrm{H} 8, \mathrm{H} 161$, and $\mathrm{H} 238$ are illustrated in Fig. 3. The three mAb are encoded by different $V_{k}$ family genes. $\mathrm{H} 161$ and $\mathrm{H} 238$ use identical $\mathrm{J}_{k} 5$ genes, whereas $\mathrm{H} 8$ is encoded by a $\mathrm{J}_{\mathbf{k}} 2$ gene.

\section{Discussion}

The results of these studies establish a relationship between a specific $\mathrm{V}$ gene sequence and the glomerular immune depositforming capacity of a subgroup of monoclonal anti-DNA Ab. The significance of these observations is emphasized by the experimental strategy used to select the $\operatorname{Ig}(11,27)$. They were independently derived from different mice, thus eliminating the use of clonally related $\mathrm{Ab}$ from an individual animal. In addition, they all shared properties with nephritogenic Ig; they cross-reacted with multiple autoAg. Most importantly, they all produced mesangial and subendothelial immune deposits after passive transfer to normal mice (11). The use of the J558 $\mathrm{V}_{\mathbf{H}}$ gene family to encode the three monoclonal anti-DNA Ab is in accord with our previous observations that Ig encoded by $V_{H}$ genes from this family may be disease relevant (12), and it is consistent with the possibility that there were shared $\mathrm{V}$ region sequences among the group.

A structure-function relationship is suggested by the near homology of the $\mathrm{V}_{\mathrm{H}} \mathrm{H} 8, \mathrm{~V}_{\mathrm{H}} \mathrm{H} 161$, and $\mathrm{V}_{\mathrm{H}} \mathrm{H} 238$ sequences. Additionally, a fourth monoclonal anti-DNA Ab, termed $\mathrm{H} 241$, that we previously observed to produce mesangial and subendothelial immune deposits that were similar to those produced by the present trio (28) was recently found to use a nearly identical $V_{H}$ gene sequence (29). This homology is particularly noteworthy because all four anti-DNA Ab (H8, H161, H238, and $\mathrm{H} 241$ ) have distinguishable CDR3 regions, and they are encoded by different $V_{L}$ genes (29). Additional disease relevance of this $V_{H}$ gene sequence is suggested by the recent report of Singh and co-workers that the $\mathrm{H} 241 \mathrm{~V}_{\mathrm{H}}$ germline gene is present in multiple autoimmune strains and absent in many normal strains (30).

Identification of a specific $\mathrm{V}$ gene sequence associated with a distinct pattern of glomerular immune deposit formation is especially remarkable, given the criteria used to select this group of autoAb. Although anti-DNA autoAb are frequently encoded by $\mathrm{J} 558$ genes, this represents the largest $\mathrm{V}_{\mathrm{H}}$ gene family, most likely including $>100$ individual genes $(31,32)$. In this regard, multiple different individual $V_{H}$ genes have been observed to encode anti-DNA $\mathrm{Ab}$, including those from both $J 558$ and other $V_{H}$ gene families $(12,18,19,33-36)$. The pathogenic relevance of this particular $V_{H}$ gene is emphasized by comparison to other previously published murine $V_{H}$ gene sequences. A few points warrant emphasis. The most closely related $\mathrm{V}_{\mathrm{H}}$ genes were used to encode anti-DNA Ab from lupus mice (Fig. $2 \mathrm{~A}$ ). The nephritogenicity of this latter group of auto $\mathrm{Ab}$ has not been examined, however, in vivo analysis would be of particular interest, since both the $V_{H} C D R 3$ region and the $V_{L}$ genes are different from those used by the present group. The results should provide additional information about the influence of regions distinct from the $V_{H}$ gene on immune deposit formation. It is highly probable that variations in these areas may either facilitate or inhibit the glomerular immune deposit formation $(29,37)$.

It is also noteworthy that this particular $J 558 \mathrm{~V}_{\mathrm{H}}$ gene is different from many other previously reported $V_{H}$ genes used to encode anti-DNA $\mathrm{Ab}$, including those derived from both MRL and other autoimmune strains (15-19, 37-39). In this regard, we and others have observed that auto $A b$ that either produce immune deposits in locations distinct from those described in the present study or do not produce immune deposits use different $V_{H}$ gene sequences $(11,13,27,37,39,40$, 41 , and unpublished observations). This includes both auto $A b$ encoded by $\mathrm{J} 558$ genes and autoAb encoded by genes that belong to different $V_{H}$ gene families. The protein sequences of prototypic J558 encoded anti-DNA Ab derived from representative MRL anti-DNA Ab, including a J558 encoded Ig that did not produce immune deposits, illustrate these differences (Fig. 4). Of additional interest, the presence of two arginines in the CDR3 region of $\mathrm{H} 8$ is consistent with the conclusions of Schlomchik and co-workers that this motif confers antidsDNA Ab activity (19). Nevertheless, this motif was not necessary for immune deposit formation; there were no cationic amino acids (His, Arg, or Lys) in the CDR3 regions of either $\mathrm{H} 238$ or $\mathrm{H} 161$, and only $2 / 22$ amino acids were cationic in the $\mathrm{V}_{\mathrm{H}}$ encoded CDR1 and CDR2 regions combined. Structural studies, in progress, should help determine the precise conformational requirements necessary for immune deposit formation.

Other $\mathrm{V}$ gene segments, distinct from this $\mathrm{V}_{\mathrm{H}}$ gene, also appear to influence both the location of immune deposit formation and the $\mathrm{Ag}$ binding properties of this group of antiDNA Ab. Accordingly, $\mathrm{H} 238$ and $\mathrm{H} 161$, the two monoclonal anti-DNA $\mathrm{Ab}$ with the most similar CDR3 regions and identical $J_{H}$ regions, both produced extraglomerular deposits in small vessels, whereas these deposits were not observed with either $\mathrm{H} 8$ or $\mathrm{H} 241$ (28). Differences in the CDR3 region and $V_{L}$ sequences also resulted in variations of the autoAg binding profiles of the MRL mAb. The influence of these segments (CDR3 and $V_{L}$ ) on Ag binding is also supported by comparison to other Ig with related $V_{H}$ gene sequences (Fig. 2); variation in autoAg binding specificities among these Ig have been observed (15-17).

The $\mathrm{V}$ gene sequence homologies also have important implications regarding the genetic origins of pathogenic auto $\mathrm{Ab}$ in murine lupus. The use of germline encoded $\mathrm{V}$ region sequences for immune deposit forming auto $\mathrm{Ab}$ is strongly suggested by the identity of the $V_{H}$ gene sequences of the independently derived MRL mAb H161 and H238, and of the (NZB $\times$ NZW)F1-derived mAb BXW16 and A52 (Fig. $2 A$ ). The $\mathrm{H} 8 \mathrm{~V}_{\mathrm{H}}$ gene differs by a single nucleotide substitution in FR1. Additionally, the $\mathrm{H} 161$ light chain appears to be encoded by $V_{L}$ and $J_{L}$ gene sequences that are identical to the BALB/c germline (20). Precisely how recombinatory and/or somatic events influence the immune deposit forming capacity of these autoAb cannot be ascertained from this initial analysis, however, we plan to evaluate the role of these processes in future experiments. A related issue is the actual number of individual $\mathrm{V}$ genes used to encode pathogenic lupus autoAb. The present results, interpreted in the context of other studies, suggest that $\mathrm{V}$ gene usage among auto $\mathrm{Ab}$ may be more limited than initially perceived $(13,15,19,37,38,42)$. This is not totally unexpected, because the antibodies were selected on the basis of 

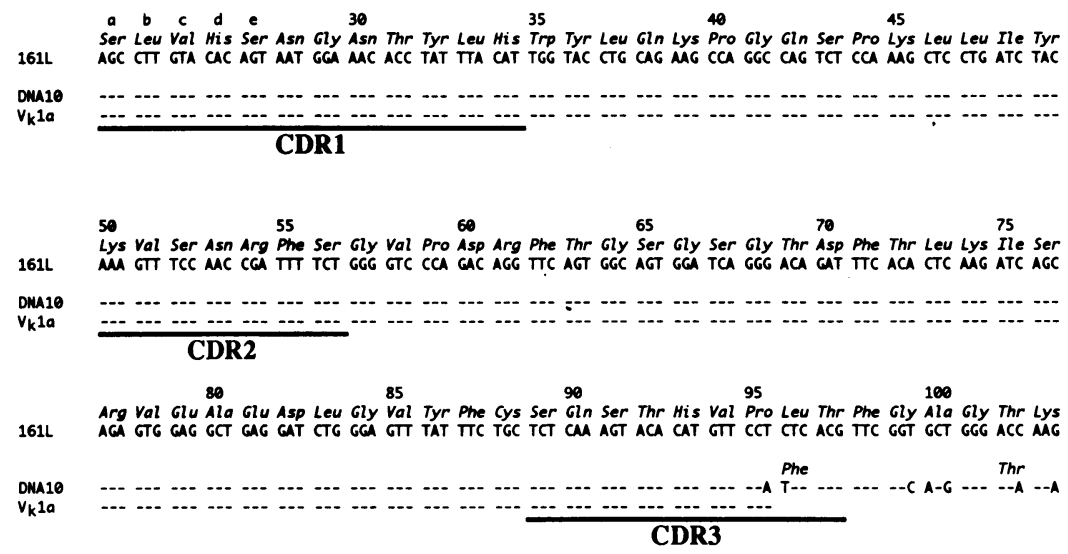

Leu Glu Leu Lys
CTG GAG CTG AAA
Ile

$\mathbf{B}$

2386 5
Glu Asn Val Met Thr Gln Ser Pro Ala Ile Met Ser Ala Thr Leu Gly Glu Lys Val Thr Met
GA AAT GTG CTC ACC CAG TCT CCA GCA ATC ATG TCT GCA ACT CTA GGG GAG AAG GTC ACC ATG $\begin{array}{ccc}25 & 30 & 35\end{array}$ Ser Cys Arg Ala Ser Ser Asn Val Lys Tyr Met Tyr Trp Tyr Gln Gln Lys Ser Gly Ala Ser
AGC TGC AGG GCC AGC TCA AAT GTA AAG TAC ATG TAC TGG TAC CAG CAG AAG TCA GG GCC TCC CDR1 45
Pro Lys Leu Leu Ile Tyr Tyr Thr Ser Asn Ler Ala Ser Gly Val Pro Ala Arg Phe Ser Gly
CCC AMA CTA TGG ATT TAT TAC ACA TCC AAC CTG GCT TCT GGA GTC CCA GCT CGC TTC AGT GGC CDR2

$238 L$ Ser Gly Ser Gly Ser Gly 7075 75 AGT GGG TCT GGG ACC TCT TAT TCT CTC ACA ATC AGC AGC GTG GAG GCT GLA Asp Ala Ala Thr Tyr Tyr Cys Gln Gln Phe Thr Ser Ser Pro Ser Thr Phe Gly Ala Gly Thr Lys Leu Glu Leu Lys
TAT TAC TGC CAG CAG TI ACT AGT TCC CCA TCC ACG TTC GG GCT GGG ACC AAG GG GAG CTG MAA CDR3
Figure 3. Nucleotide and deduced a.a. sequence of the light chain genes of $\mathrm{H} 161(A), \mathrm{H} 238(B)$, and $\mathrm{H} 8$ $(C)$. The $\mathrm{mAb}$ were encoded by different $\mathrm{V}_{\mathrm{k}}$ families: $\mathrm{H} 161, \mathrm{~V}_{\mathrm{k}} 1 ; \mathrm{H} 238, \mathrm{~V}_{\mathrm{k}} 4$ and $\mathrm{H} 8, \mathrm{~V}_{\mathrm{k}} 8$. Antibodies encoded by $V_{L}$ sequences identified by GenBank that showed the greatest homology with the anti-DNA $\mathrm{Ab}$ include $(A) \mathrm{H} 161$. DNA10 a MRL-lpr/lpr anti-DNA $\mathrm{Ab}$ (15) and $\mathrm{V}_{\mathrm{k}} \mathrm{la}$, a BALB/c germline gene (20). Not shown are DNA4, a MRL-lpr/lpr anti-DNA Ab (15); V105, a BALB/c myeloma kappa chain (21); 29-IG5, a BALB/c anti-GAT Ab (22); and GP13810 , a MRL-lpr/lpr-derived $A b$ (17) all sharing > 99\% homology. (B) H238. The most homologous Ig (not shown ) were AN09K, a BALB/c-derived anti-DNP $\mathrm{Ab}$ (23); and $\mathrm{V}_{5}-\mathrm{J}_{3}$, a nonproductively rearranged $\mathrm{V}_{\mathrm{k}} 4$ gene derived from an NZB mouse sharing $95 \%$ homology (24). (C) H8. AM13 (19) an MRL-lpr/ lpr-derived rheumatoid factor. Not shown are H21056, a BALB/c-derived anti Influenza HA Ab (25) and 180.2G6, a BALB/c-derived antiphosphocholine $A b$ (26) with $96.5 \%$ homology. their Ag binding specificities (i.e., anti-DNA). Nevertheless, the observed diversity in disease expression among J558 encoded anti-DNA Ab indicates that relatively subtle differences in the $\mathrm{Ag}$ binding region have profound effects on nephritogenicity.

This conclusion is also supported by previous evaluation of the relative contribution of variable region segments to the pathogenic potential of lupus autoAb. Reininger and coworkers demonstrated the importance of the heavy chain of an MRL-lpr/lpr-derived monoclonal rheumatoid factor (cryoglobulin) that transferred glomerulonephritis and cutaneous vasculitis to normal mice (40). Hybrid molecules, consisting of the original heavy chain associated with a novel light chain, retained cryoglobulin activity and induced glomerulonephritis, but did not produce vasculitis, supporting an influential role for the $\mathrm{Ag}$ binding region in disease expression. Using a related approach, Radic and co-workers observed variability in the anti-DNA activity of an MRL-lpr/lpr-derived mAb (43). A requirement for specific combinations of $\mathrm{V}$ gene segments for the production of pathogenic potential of lupus auto $\mathrm{Ab}$ is consistent with the observations of Tsao and co-workers. They observed that the $\mathrm{V}_{\mathbf{H}}$ gene encoding a $(\mathrm{NZB} \times \mathrm{NZW}) \mathrm{F} 1$-derived pathogenic anti-DNA $A b$ was nearly identical to the $V_{H}$ gene of a nonpathogenic MRL-lpr/lpr-derived anti-DNA Ab, however the other $\mathrm{V}$ region segments were distinct from one another (37).

It is evident from these reports that different $V_{H}$ genes may be used to encode pathogenic autoAb. This conclusion is also 


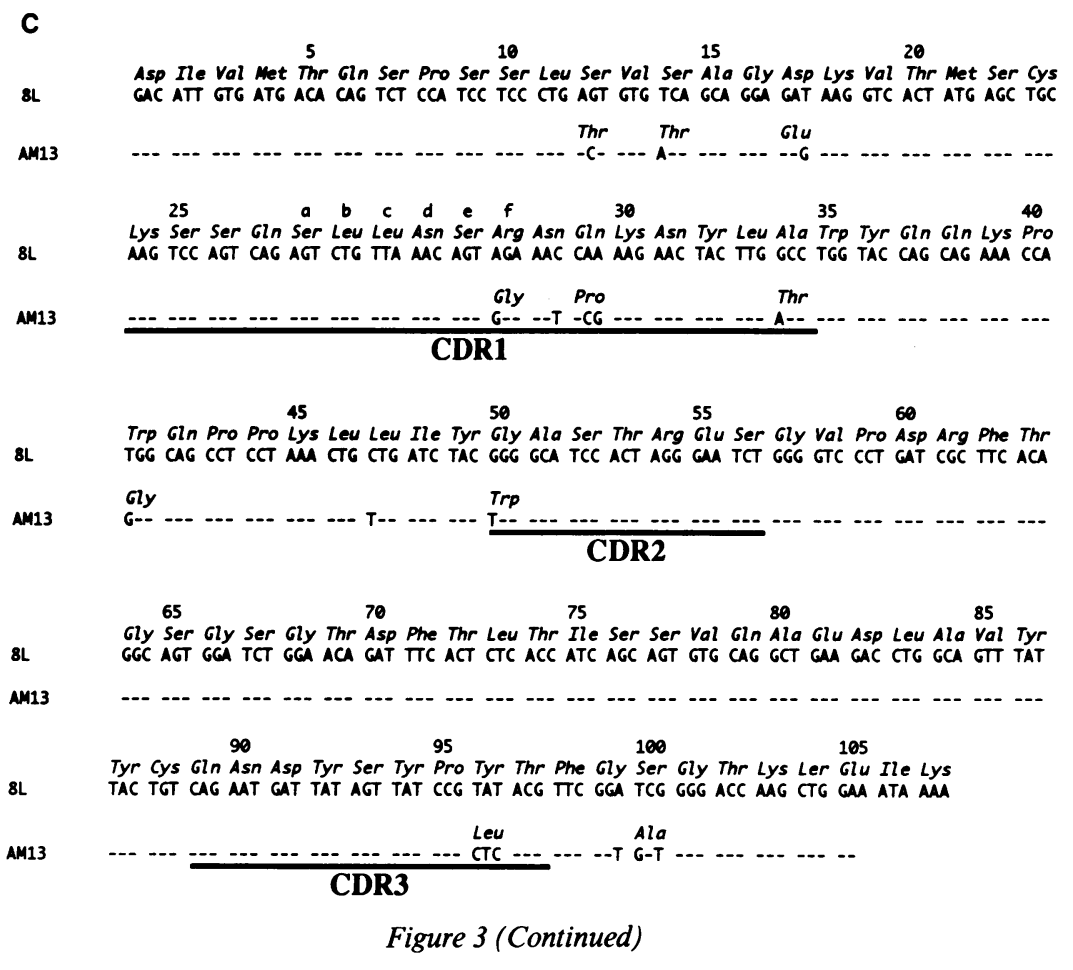

supported by our previous observations in SNF1 mice. Although three clonally related anti-DNA antibodies all produced glomerular immune deposits and glomerulonephritis after passive transfer to predisease SNF1 mice, their $V_{H}$ gene was not highly related to the $V_{H}$ gene sequence of the nephritogenic Ig described above $(11,39)$. Different mechanisms of immune deposit formation may account for the observed disparities. In this regard, we previously reported that morphologically distinct lesions developed after the administration of indi-

vidual anti-DNA $A b$ to normal mice (11). Alternatively, although the primary sequences of the latter autoAb are different from those reported herein, similar conformationally dependent residues within the $\mathrm{Ag}$ binding regions of the individual auto $A b$ could serve to interact with the same ligand to initiate immune deposit formation. Structural analysis of both the pathogenic autoAb and the relevant target antigens should provide clues to the mechanisms underlying these pathologic processes.
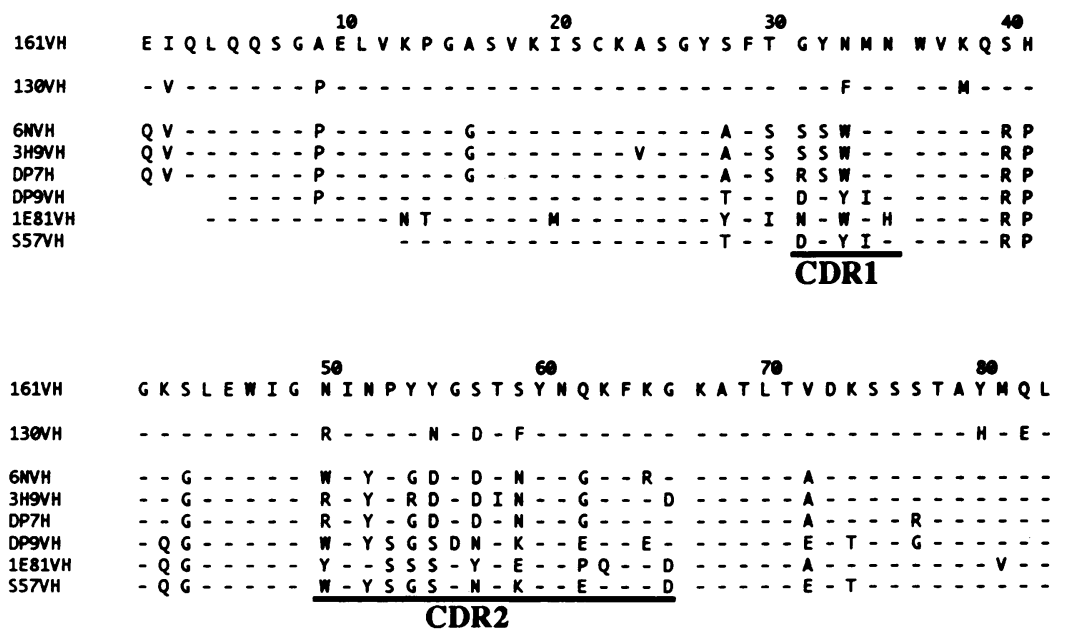

Figure 4. Comparison of deduced amino acid sequence of $\mathrm{V}_{\mathrm{H}} \mathrm{H} 161$ to $\mathrm{H} 130$, a nonpathogenic MRL$\mathrm{lpr} / \mathrm{lpr}$ anti-DNA Ab (18), and representative J558 encoded anti-DNA $A b$ from a large panel of MRL lpr/lpr Ab from multiple mice (19). Each mAb. within the latter panel is representative of a clonally expanded population from an individual mouse. 


\section{Acknowledgments}

We thank Kathleen J. Barrett for critical review of the manuscript.

This work was supported by Public Health Service grant DK 33694

to M. P. Madaio, Public Health Service grant DK 09104 to M. H. Foster, Sheryl N. Hirsch Awards of the Lupus Foundation of Philadelphia to M. H. Foster and M. P. Madaio, and a George M. O'Brien Renal Center Grant DK-45191.

\section{References}

1. Koffler, D., P. H. Schur, and H. G. Kunkel. 1967. Immunologic studies concerning the nephritis of systemic lupus erythematosus. J. Exp. Med. 126:607624.

2. Sasaki, T., A. Hatakeyama, S. Shibata, H. Osaki, M. Suzuki, K. Horie, Y. Kitagawa, and K. Yoshinaga. 1991. Heterogeneity of immune complex-derived anti-DNA antibodies associated with lupus nephritis. Kidney Int. 39:746-753.

3. Pankewycz, O. G., P. Migliorini, and M. P. Madaio. 1987. Polyreactive autoantibodies are nephritogenic in murine lupus nephritis. J. Immunol. 139:3287-3294.

4. Sabbaga, J., O. G. Pankewycz, V. Luff, R. S. Schwartz, and M. P. Madaio. 1990. Cross-reactivity distinguishes serum and nephritogenic anti-DNA antibodies in human lupus from their natural counterparts in normal serum. J. Autoimmun. 3:215-235.

5. Gavalchin, J., R. A. Seder, and S. K. Datta. 1987. The NZB $\times$ SWR model of lupus nephritis. I. Cross-reactive idiotypes of monoclonal anti-DNA antibodies in relation to antigenic specificity, charge, and allotype. Identification of interconnected idiotype families inherited from the normal SWR and the autoimmune NZB parents. J. Immunol. 138:128-137.

6. Ebling, F., and B. H. Hahn. 1980. Restricted subpopulations of DNA antibodies in kidneys of mice with systemic lupus: comparison of antibodies in serum and renal eluates. Arthritis Rheum. 23:392-403.

7. Yoshida, H., M. Yoshida, S. Izui, and P. H. Lambert. 1985. Distinct clonotypes of anti-DNA antibodies in mice with lupus nephritis. J. Clin. Invest. 76:685-694.

8. Faaber, P., P. J. A. Capel, G. P. M. Rijke, G. Vierwinden, L. B. A. Van de Putte, and R. A. P. Koene. 1984. Cross-reactivity of anti-DNA antibodies with proteoglycans. Clin. Exp. Immunol. 55:502-508.

9. Hahn, B. H., and F. M. Ebling. 1987. Idiotype restriction in murine lupus: high frequency of three public idiotypes on serum IgG in nephritic NZB/NZW F1 mice. J. Immunol. 138:2110-2118.

10. Isenberg, D. A., and C. Collins. 1985. Detection of cross-reactive antiDNA antibody idiotypes on renal tissue-bound immunoglobulins from lupus patients. J. Clin. Invest. 76:287-294.

11. Vlahakos, D. V., M. H. Foster, S. Adams, M. Katz, A. A. Ucci, K. J. Barrett, S. K. Datta, and M. P. Madaio. 1992. Monoclonal anti-DNA antibodies derived from lupus-prone mice form immune deposits at distinct glomerular and vascular locations. Kidney Int. 41:1690-1700.

12. Foster, M. H., M. MacDonald, K. J. Barrett, and M. P. Madaio. 1991. VH gene analysis of spontaneously activated B cells in adult MRL-lpr/lpr mice. The J558 bias is not limited to classic lupus autoantibodies. J. Immunol. 147:15041511 .

13. Foster, M. H., M. P. Madaio, and K. J. Barrett. 1992. Variable Region Sequence analysis of anti-DNA antibodies: evidence for a family of closely related germ line VH genes encoding lupus autoantibodies. DNA Cell Biol. 11:175-182.

14. Kabat, E. A., T. T. Wu, M. Reid-Miller, H. M. Perry, and K. S. Gottesman. 1987. Sequences of Proteins of Immunological Interest. U. S. Department of Health and Human Services, Bethesda, MD. 508-525.

15. Kofler, R., R. Strohal, R. S. Balderas, M. E. Johnson, D. J. Noonan, M. A Duchosal, F. J. Dixon, and A. N. Theofilopoulos. 1988. Immunoglobulin $k$ light chain variable region complex organization and immunoglobulin genes encoding anti-DNA autoantibodies in lupus mice. J. Clin. Invest. 82:852-860.

16. Eilat, D., D. W. Webster, and A. R. Rees. 1988. V region sequences of anti-DNA and anti-RNA autoantibodies from NZB/NZW F1 mice. J. Immunol. 141:1745-1753.

17. Baily, N. C., V. Fidanza, R. Mayer, G. Mazza, M. Fougereau, and C Bona. 1989. Activation of clones producing self-reactive antibodies by foreign antigen and antiidiotype antibody carrying the internal image of the antigen. $J$. Clin. Invest. 84:744-756.

18. Trepicchio, W. J., A. Maruya, and K. J. Barrett. 1987. The heavy chain genes of a lupus anti-DNA autoantibody are encoded in the germline of a non-autoimmune mouse strain and conserved in strains of mice polymorphic for this gene locus. J. Immunol. 139:3139-3145.

19. Schlomchik, M., M. Mascelli, H. Shan, M. Z. Radic, D. Pisetsky, A Marshak-Rothstein, and M. Weigert. 1990. Anti-DNA autoantibodies from au- toimmune mice arise by clonal expansion and somatic mutation. J. Exp. Med. 171:265-292.

20. Ng, K. H., A. Lavigueur, L. Ricard, M. Bouvrette, S. MacLean, D. Cloutier, and D. M. Gibson. 1989. Characterization of allelic Vk-1 region genes in inbred strains of mice. J. Immunol. 143:638-648.

21. Moynet, D., S. J. MacLean, K. H. Ng, D. Anctil, and D. M. Gibson. 1985. Polymorphism of kappa variable region (V-kappa-1) genes in inbred mice: Relationship to the Ig-kappa-Ef2 serum light chain marker. J. Immunol. 135:727732.

22. Busto, P., R. Gerstein, L. Dupre, C. A. Giorgetti, E. Selsing, and J. L. Press. 1987. Molecular analysis of heavy and light chains used by primary and secondary anti-( T,G)-A-L antibodies produced by normal Xid mice. J. Immunol. 608-618.

23. Leahy, D. J., G. S. Rule, N. M. Whittaker, and H. M. McConnell. 1988 Sequence of 12 monoclonal anti-dinitrophenol spin-label anti-bodies for NMR studies. Proc. Natl. Acad. Sci. USA. 85:3661-3665.

24. Kelley, D. E., L. M. Wiedemann, A. C. Pittet, S. Strauss, K. J. Nelson, J. Davis, B. Van Ness, and R. P. Perry. 1985. Nonproductive kappa immunoglobulin genes: recombinational abnormalities and other lesions affecting transcription, RNA processing turnover, and translation. Mol. Cell. Biol. 5:1660-1675.

25. Clarke, S., L. M. Staudt, J. Kavaler, D. Schwartz, W. U. Gerhard, and M. G. Weigert. 1990. V Region Gene Usage and Somatic Mutation in the Primary and secondary responses to influenza virus hemagglutinin. J. Immunol. 144:2795-2801.

26. Claflin, J. L., J. Berry, D. Flaherty, and W. Dunnick. 1987. Somatic evolution of diversity among anti-phosphocholine antibodies induced with proteus morganii. J. Immunol. 138:3060-3068.

27. Vlahakos, D., M. H. Foster, A. A. Ucci, K. J. Barrett, S. K. Datta, and M. P. Madaio. 1992. Murine monoclonal anti-DNA antibodies penetrate cells, bind to nuclei, and induce glomerular proliferation and proteinuria in vivo. $J$. Am. Soc. Nephrol. 2:1345-1354.

28. Madaio, M. P., J. Carlson, J. Cataldo, A. Ucci, P. Migliorini, and O. G. Pankewycz. 1987. Murine monoclonal anti-DNA antibodies bind directly to glomerular antigens and form immune deposits. J. Immunol. 138:2883-2894.

29. Singh, A. K., R. Gangemi, and K. J. Barrett. 1991. The D and/or $V_{L}$ gene may determine the nephritogenicity of anti-DNA antibodies in MRL-lpr/lpr mice. J. Amer. Soc. Neph. 2:563 (Abstr.)

30. Singh, A. K., R. Gangemi, and K. J. Barrett. 1990. Structural and genetic determinants of immune deposition in lupus nephritis. J. Am. Soc. Nephrol. 1:540 (Abstr.)

31. Brodeur, P. H. 1987. In Molecular Genetics of Immunoglobulin. F. Calabi and M. S. Neuberger, editors. Elsevier Science Publishing Corp., New York. 81-109.

32. Livant, D., C. Blatt, and L. Hood. 1986. One heavy chain variable region gene segment subfamily in the BALB/c mouse contains $500-1,000$ or more members. Cell. 47:461-470.

33. Komisar, J. L., K. Y. Leung, R. R. Crawley, N. Talal, and J. M. Teale. 1989. Ig VH repertoire of plasma cells derived from lupus-prone MRL/lpr and MRL/++ mice. J. Immunol. 143:340-347.

34. Klinman, D. M., and A. D. Steinberg. 1987. Systemic autoimmune disease arises from polyclonal B cell activation. J. Exp. Med. 165:1755-1760.

35. Trepicchio, W., Jr., and K. J. Barrett. 1987. Eleven MRL-lpr/lpr antiDNA autoantibodies are encoded by genes from four different $\mathrm{VH}$ gene families: a potentially biased usage of VH genes. J. Immunol. 138:2323-2331.

36. Panosian-Sahakian, N., J. L. Klotz, F. Ebling, M. Kronenberg, and B. Hahn. 1989. Diversity of Ig V gene segments found in anti-DNA autoantibodie from a single (NZB $\times$ NZW)F1 mouse. J. Immunol. 142:4500-4506.

37. Tsao, B. P., F. M. Ebling, C. Roman, N. Panosian-Sahakian, K. Calame, and B. H. Hahn. 1989. Structural characteristics of the variable regions of immunoglobulin genes encoding a pathogenic autoantibody in murine lupus. J. Clin. Invest. 85:530-540.

38. Marion, T. N., D. M. Tillman, and N. T. Jou. 1990. Interclonal and intraclonal diversity among anti-DNA antibodies from an (NZB $\times$ NZW)F mouse. J. Immunol. 145:2322-2332.

39. O'Keefe, T., S. Bandyopadhyay, S. K. Datta, and T. Imanishi-Kari. 1990 $V$ region sequences of an idiotypically connected family of pathogenic anti-DNA autoantibodies. J. Immunol. 144:4275-4283.

40. Reininger, L., T. Berney, T. Shibata, F. Spertini, R. Merino, and S. Izui. 1990. Cryoglobulinemia induced by a murine IgG3 rheumatoid factor: skin vasculitis and glomerulonephritis arise from distinct pathogenic mechanisms. Proc. Natl. Acad. Sci. USA. 87:10038-10042.

41. Gavalchin, J., and S. K. Datta. 1987. The NZB $\times$ SWR model of lupus nephritis. II. Autoantibodies deposited in renal lesions show a distinctive and restricted idiotypic diversity. J. Immunol. 138:138-148.

42. Carson, D. A. 1991. The specificity of Anti-DNA antibodies in systemic lupus erythematosus. J. Immunol. 146:1-2.

43. Radic, M., M. A. Mascelli, J. Erikson, H. Shan, and M. Weigert. 1991. Ig $H$ and $L$ chain contribution to autoimmune specificities. J. Immunol. 146:176182. 